\title{
The Torah Speaks to People
}

Chezi Cohen

\section{Introduction}

The belief that the Torah was revealed by God is one of the cornerstones of Jewish faith. The Bible contains so many accounts of revelation that the event does not elicit astonishment from either the narrator, the listener, or the recipient of the revelation. ${ }^{1}$ God's revelation to humankind is comprised of two elements: God the revealer and the human recipient to whom this revelation is directed. ${ }^{2}$ The concept that God is beyond human comprehension could theoretically, although not necessarily, extend to divine discourse, the Torah. Jewish tradition includes various models for understanding the nature of the Torah. The belief that the Torah can be understood only by deciphering the secrets encrypted within it occupies one end of the spectrum. On the other end lies the position that the Torah can be understood only by means of human capabilities. Between these two extremes there stretches a wide spectrum of possibilities.

On one extreme, there is an approach that identifies God with his Torah, as can be seen in the following midrash: "I the Lord am your God' (Exod. 20:2) —What does 'I' mean? Rav said: 'You will not mock the Torah that I gave you. "I" (anochi) is an acronym for "I, myself, wrote it and gave it" (ana nafsi kitveit yahaveit)."3

Identifying God with his Torah leads to the understanding that every detail, even the smallest, in the Torah has meaning and significance, even the shapes of the letters. This approach can be attributed to Rabbi Akiva, who drew meaning from every letter in the Torah, including from their shapes. His underlying assumption was that the Torah speaks in an encrypted divine language that can be deciphered and understood by means of the rabbinic hermeneutical rules. An example of Rabbi Akiva's method can be found in the Babylonian Talmud, tractate Sanhedrin 51b, where he deduces from the addition of a conjunctive letter vav the method of execution appropriate for a Kohen's adulterous 
daughter: "Rabbi Akiva said: '[A priest's daughter], whether betrothed or married is executed by burning [rather than the lighter punishment of strangulation].' . . . Rabbi Akiva replied: 'Ishmael, my brother, I deduce this from the addition of the letter vav to the word "daughter" (Lev. 21:9). Rabbi Ishmael said to him: 'Because you make this fine distinction, should we execute this woman by burning rather than strangulation?”

According to Rabbi Akiva, the Torah is a closed system with its own unique language that cannot be deciphered by human intelligence. The Torah scholar must therefore make use of the system of divine hermeneutical rules for the interpretation of the Torah. Many have followed this path, including Jacob ben Asher and the author of Sefer Yetzirah.

An opposite approach posits that the Torah is the word of God given to man, and is thus limited in its language and contents. This idea is expressed in rabbinic literature by the phrase "the Torah uses human language." According to this approach, meaning cannot be extracted from every superfluous word in the biblical text because the Torah is written according to human forms of expression. As we have seen, Rabbi Ishmael advanced this argument against Rabbi Akiva in the case of the adulterous daughter of the Kohen. Another example can be found in tractate Sanhedrin 56a, where the sages rejected Rabbi Meir's deduction on the basis of the repetition in the verse "Anyone (ish ish) who blasphemes his God" (Lev. 24:15), and explained the verse as conforming to patterns of human speech: "What of it? The Torah uses human language."

This phrase is repeated often in the Talmud regarding verses that contain either a repetition of words, or use the verb both in the infinitive and inflected forms. An additional example can be found in the rabbinic dispute over whether a freed slave should be given a severance payment in all cases. The dispute concerns the meaning of Deuteronomy 15:13: "When you set him free, do not let him go empty-handed: Furnish him out of the flock, threshing floor, and vat." Some deduced from the repetition of the verbal root in the phrase "furnish him" (ha'aneik ta'anik) that there is always an obligation to grant the slave the payment. Rabbi Elazar ben Azariah, however, limited the payment to slaves who had brought prosperity to the master's household, and thus explained the redundancy as a figure of human speech:

Our Rabbis taught: "With which the Lord your God has blessed you" (Deut. 15:14) —One might think that this means that if the household was blessed on his account, the master must give him the payment, but if the household was not blessed on his account, he does not have to pay 
him. Therefore, the Torah says "furnish him" (15:14)—in any case. If so, what is the meaning of the words "with which the Lord your God has blessed you"? [It means] give him according to the blessing that you have received. Rabbi Elazar ben Azariah said: "The matter is as it is written: if the house was blessed on his account, a gift is made to him; if the house was not blessed on his account, no gift is made to him." If so, what is meant by "thou shalt surely furnish him"? The Torah uses human language. ${ }^{4}$

This approach is based on the understanding that it is impossible to construct a theology that ignores the human nature of the Torah's recipients. Another midrash expresses the same idea in different words: "The Torah uses language that its audience can comprehend" (literally, "that the ear can hear"). ${ }^{5}$ Many thinkers and exegetes, in particular Maimonides, expanded on this idea. ${ }^{6}$

The principle underlying this approach is that, while God is infinite, the Torah is finite because it was given to human beings in a limited physical world. The transmission of the Torah to the People of Israel, as well as its temporal subject matter, makes this conclusion axiomatic. Thus, although God's power and might fill the world, in His encounter with limited mortals God constricts Himself and accepts the rules of this world. Therefore, biblical exegesis mandates consideration of the human nature of the Torah's recipients. This exegetical method is called peshat, an obscure term with many definitions. Abraham Ibn Ezra, in the introduction to his commentary on the Torah, defined peshat as an exegetical approach "bound by the rules of grammar and acceptable to reason"; in other words, the interpretation must be linguistically correct and seem logical to the reader. The exegete Samuel ben Meir (Rashbam) explained it differently: "If the reader has seen previous commentaries that lean toward a different meaning regarding other matters, he should take note that these are not based on social mores, according to human wisdom, or that this is not the meaning of the verse ... whereas I have explained them well according to both the text of the verses and social mores." 7

These definitions express the central idea of this article-that exegesis must be clear to the reader using his common sense. ${ }^{8}$ I will explain below that this applies specifically to the reader at the time of the revelation. It must be noted here that it is possible to propose other models for understanding peshat. In contrast to a radical approach that claims that there is only the peshat, Samuel ben Meir suggested that the Torah contains various additional layers, including esoteric meanings. However, even according to this approach, in the end, "the biblical text never loses its peshat meaning." 


\section{Distinguishing between God and his Torah}

In contrast to the identification of God with his Torah seen in the midrash cited above (pesikta 12), the following midrash makes a clear distinction between the two:

They asked Wisdom: "How should a sinner be punished?" Wisdom answered: "Misfortune pursues sinners" (Prov. 13:21). They asked Prophecy: "How should a sinner be punished?" Prophecy answered: "The person who sins, only he shall die" (Ezek. 18:4). They asked the Torah: "How should a sinner be punished?" The Torah answered: "He should bring a sin offering and he will be forgiven." They asked God: "How should a sinner be punished?" God answered: "He should repent and he will be forgiven, as it is written: 'Good and upright is the Lord; therefore He shows sinners the way”' (Ps. 25:8). ${ }^{10}$

According to this midrash, the Torah and God are two separate entities who give different answers to the question of the appropriate punishment for sin! Although the Torah is on a higher level than wisdom and prophecy, there is an even higher level: the answer of God Himself, as it were. ${ }^{11}$ In the Torah, offering a sacrifice brings atonement. God, however, wants repentance. Are prophecy and Torah not the will of God? They certainly are, but they express only a certain aspect of the divine will; his deeper will (if this is the right word for it) has a different answer to the question. The most astounding aspect of this midrash is that God cites his answer from the book of Psalms - written by a man! God's answer is encrypted in man's prayer. ${ }^{12}$

We must also differentiate between God and his Torah on a conceptual level. While God is infinite, the Torah is limited. Although it is on a higher plane than other forms of divine expression (wisdom and prophecy), it is not God Himself. In order to clarify this point, I will make use of a wellknown parable - a person speaking with a small child must limit himself to the child's vocabulary. So too God constricts himself when he speaks to us in the Torah:

A parable of a man who has a very beloved young son ... the father will not speak with him according to his own sophisticated and extensive intellect, because the son will not be able to comprehend or understand him. Because of the intensity and the strength of his love for his beloved son, he 
constricts his great and vast intellect immeasurably and speaks to his son according to the child's undeveloped and immature intellect. ${ }^{13}$

A similar, although not identical, differentiation appears in kabbalistic literature that distinguishes between the primordial Torah and the Written Torah. This idea was adopted by Tamar Ross, ${ }^{14}$ who argues that the primordial Torah is the reflection of God in His essence. It is a clear reflection of the secrets of His infinite wisdom, free from the finiteness of human understanding, a spiritual entity beyond this world. In contrast, the Written Torah is a reflection or shadow of this primordial infinite form. It embodies the celestial Torah, but inevitably does so in a more restricted context, anchored in the temporal dimension.

Despite differences in terminology (primordial Torah/God), the distinction between the sublime God and our Torah is common to both approaches. From this distinction, it can be concluded that any peshat interpretation must take into account human capacity. ${ }^{15}$ My teacher Rabbi David Bigman has noted that the Torah, though eternal, was originally given to the first generation. In other words, along with the infinite meaning of the Torah, there is also a particular meaning for the time in which it was given. From this it may be concluded that we are compelled to search for the most reasonable peshat explanation by taking into account the human aspect in the process of transmission.

In this context it is important to distinguish between two hermeneutic concepts: rational interpretation as opposed to logical interpretation. The first includes any possible interpretation from within the range of options, even if its likelihood is very remote. In contrast, logical interpretation is very likely, perhaps even most likely, to be correct. For example, the sages identified Agag, the king of Amalek, who fought against Saul, with Haman the Agagite. According to a midrash, Agag had relations with a servant girl before he was executed by the prophet Samuel, and in due course Haman the Agagite was born from this union. ${ }^{16}$ This interpretation is theoretically possible, although the likelihood is remote and the identification is tenuous. If there is a connection between Haman and the Amalekites, it is more likely that Haman is the descendent of other Amalekites (see, e.g., 1 Sam. 30:17). Neither of these terms is absolute; their meanings change constantly. Their likelihood is determined by an understanding of the cultural, linguistic, and historical context of the text and its author. Nevertheless, the peshat exegete must aspire to present the most logical interpretation. 


\section{Receiving the Torah: Including the Recipient in the Development of Theology}

The Torah's use of human language is reflected in several areas:

\section{The Torah's Areas of Interest}

The Torah contains many references to idolatry, a common practice in the ancient world. It does not mention atheism, a concept that did not exist at the time in which the Torah was given, and would not have been understood by its original readers. Similarly, the Torah refers extensively to sacred prostitution because it was endemic to ancient Near Eastern culture; today, however, this practice is virtually unknown. ${ }^{17}$ Likewise, the tribal division of the Children of Israel weakened and disappeared over the course of time, and as a result the laws of inheritance of land lost their significance.

\section{Linguistics}

God is limited when speaking to people; he had to address the People of Israel in a language that they understood. The Torah is therefore written in ancient Hebrew, including forms of speech not in use in modern Hebrew. For example, the use of the infinite with the inflected verb as in hakem takim; the addition of a vav to a verb in the future tense to create a past tense verb, as in va-yidaber. God constricts himself and uses a very limited vocabulary. In addressing the original recipients of the Torah, he did not use words from modern Hebrew or from foreign languages with which they were unfamiliar, though he was capable of doing so.

Peshat interpretation must reflect an understanding of the syntax and vocabulary of the Hebrew language as it would have been intelligible to the generation that received the Torah. Thus Rabbi Akiva's explanation of the word totafot (Deut. 6:8; understood to mean "tefillin") that "tot means two in Coptic and fot means two in African" is a midrash. ${ }^{18}$ God is, of course, capable of speaking different languages. It cannot, however, be argued that the Torah, which was given to the People of Israel, includes a word combining elements from two languages not current in the ancient Near East, a word that the People of Israel could not have understood. In this case, I prefer the explanation of Menahem ibn Saruq that totafot derives from the word hatafa (exhortation), meaning that "one who sees them [the tefillin] between the eyes will remember the miracle and speak of it." ${ }^{19}$ The suggestion, made by other commentators on the basis of the context and parallel structure, that the word refers to a type of jewelry is also plausible. ${ }^{20}$ 
Similarly, the sentence structure in the Torah follows syntax familiar to the People of Israel at the time that they received the Torah-usually the predicate followed by the subject as in vayidaber Hashem el ... (literally, "and spoke God to ...") - in contrast to current syntax — the subject followed by the predicate, as in "God spoke to." Thus, a sentence structured in a different syntactic form (subject-predicate) is irregular, and this irregularity must be explained according to exegetical principles. For example, the verse "Now the man knew his wife Eve" (Gen. 4:1) is explained by Rashi as the distant past "previous to the matter related above, before he had sinned and was banished from the Garden of Eden, as well as the pregnancy and the birth, because if it had been written vayeda adam (literally, "knew, the man"), it would mean that the children were born after the expulsion."21 God had to speak to the People of Israel in the form current at the time of the giving of the Torah. Examples of this can be found in biblical literature in the parallel structure of poetry; the chiastic structure, characteristic of Near Eastern literature, found in many biblical stories; ${ }^{22}$ and the frequent use of typological (formulaic) numbers. ${ }^{23}$

\section{Language}

These conclusions apply also to the concept of "language" in the wider sense of the term. The images that God used in the Torah are taken from the world familiar to people in the time of the Bible. Reward and punishment revolve around rain and agricultural produce (see, e.g., Deut. 11) that people at that time depended on for sustenance. This reality is foreign to the modern, urban lifestyle.

The personification of God was a response to the difficulty of discussing an abstract deity, as can be seen in the midrash cited above: "The vision of the glory of God is like a consuming fire at the summit of the mountain. The Torah spoke in a language that its audience could comprehend ... and there are many examples of this ... to draw them closer to his uniqueness."24

Reference to God in masculine grammatical forms is also an example of the use of human language. In a male-dominated, patriarchal society, this would have been the natural form of reference.

\section{Conceptions of Nature and the Universe}

The cosmology presented in the Torah is radically different from modern cosmology. The Torah describes the heavens as a rakia (expanse), meaning a physical partition separating the upper waters from the lower waters 
(Gen. 1:6). Rain falls through floodgates in the sky ("And the floodgates of the sky broke open" (Gen. 7:11). The earth rests on pillars-"For the pillars of the earth are the Lord's; He has set the world upon them" (1 Sam. 2:8) — and underneath it lies Sheol, the underworld: "Sheol below was astir" (Isa. 14:9). The central aspects of this cosmology have parallels in Near Eastern literature. ${ }^{25}$ How should we understand this in light of the very different cosmology presented by modern science? Is the Torah wrong? The Torah was given to people and it communicated with them according to their worldview. This was the scientific knowledge current at the time when the Torah was given, and the Torah does not contradict what is known to man. If so, we can conclude that the entire description of the creation of the world is couched in human language, and expresses important principles: the world was created by God; it is harmonic; man was created in the image of God. Modern man is required to act in accordance with these principles and, at the same time, can accept without hesitation modern theories about the creation of the universe. ${ }^{26}$

\section{The Laws of the Torah}

Do the laws of the Torah reflect a divine ideal? Many sources indicate that the Torah took into consideration the inclinations of man in its legislation, and is adapted in detail to the time in which it was given.

A prime example of this is the law of the "beautiful captive" (Deut. 21:11). The sages declared that this law was not ideal: "The Torah only decreed this in order to protect against man's evil inclination” (Babylonian Talmud, tractate Kiddushin 21b). In other words, the Torah established its laws out of familiarity with the human, instinctive, nature of man, and this implies a certain degree of relativity. In a world in which the rape of female captives was accepted practice, and even considered a kind of legitimate payment for the soldier (see Judg. 5:30), the commandment concerning the beautiful captive is understandable and crucial. The Torah allowed her to be taken, but demanded that relations with her be consecrated, and thus required the soldier to marry her: "The Torah only made considerations for the evil inclination; it is better for Israel to eat the flesh of dying animals, ritually slaughtered, than flesh of animals who died of natural causes." 27

Rashi commented on this passage: “A beautiful woman'-because he lusts for her on account of her beauty, she is permitted to him, but only just; it is preferable for the People of Israel to eat the flesh of dying animals that have 
been ritually slaughtered, or unhealthy meat that has been slaughtered, even if it is disgusting."

It is obvious that the central message of the commandment concerning the beautiful captive, revolutionary in its time, is eternal. The intention to minimize vulgarity and violent, unchecked sexual desire, even during war, is a basic principle that remains relevant today. Ironically, because this principle has been accepted and the modern world condemns rape and pillage, the particular details of this commandment are no longer relevant.

A classic example of exegesis based on the concept that law reflects its historical context is Maimonides' position that God commanded sacrifices because this was the universal form of ritual at the time when the Torah was given. The People of Israel were unable to accept a Torah that did not include sacrificial rites. The purpose of the commandments was to divert the sacrificial service performed by the People of Israel from idolatry to the worship of God:

And therefore man, according to his nature, is not capable of abandoning suddenly all to which he was accustomed ... and, as at that time the way of life generally accepted and customary in the whole world and the universal service upon which we were brought up consisted in offering various species of living beings in the temples in which images were set up ... His wisdom, may He be exalted, and his gracious ruse, which is manifest in regard to all his creatures, did not require that He give us a Law prescribing the rejection, abandonment, and abolition of all these kinds of worship. For one could not then conceive the acceptance of [such a Law], considering the nature of man, which always likes that to which it is accustomed. At that time this would have been similar to the appearance of a prophet in these times who calling upon the people to worship God, would say: "God has given you a Law forbidding you to pray to Him, to fast, to call upon Him for help in misfortune. Your worship should consist solely in meditation without any works at all." 28

Maimonides regarded the sacrificial rite as the prototype of all the commandments, designed to perfect multiple aspects of the human personality, and thus deemed it necessary to understand these commandments in the historical context in which they were given.

Another example can be found in the laws of blood vengeance (Num. 35:9-34). The Torah allows the family of a victim of manslaughter to kill 
the perpetrator as long as he has not entered a city of refuge. Is this an ideal situation? It is clear that the Torah intended to reduce the existing widespread practice of blood vengeance, not to institutionalize it.

According to the prevailing custom, the victim's family attempted to take revenge upon the killer (whether he acted intentionally or accidentally) and his family. Near Eastern law codes allowed the accidental murderer to pay a ransom. ${ }^{29}$ In practice, many blood feuds continued over many years (see, e.g., 2 Sam. 3:27). ${ }^{30}$

In contrast, the Torah decreed that intentional killers would be put to death only after due legal process, and limited the opportunity for exacting vengeance on accidental killers to the time preceding arrival at the city of refuge, or in the event of premature departure from it. In addition, a killer's stay in the city of refuge would end upon the death of the High Priest. These changes herald an important legal development and social progress. The accidental killer does not have to pay a ransom and, more importantly, the period of time in which he may be killed in revenge is very brief. When humanity reached a state of further progress, blood vengeance ceased to exist within Jewish society as in most other societies.

The approach presented here, namely that the Torah is adapted to the time it was given, and, thus, to a reality different from the one in which we live, immediately raises the question of the Torah's eternal validity. If the Torah is subject to the influence of time and place, is it possible that it will change in the future?

Maimonides, who argued that the Torah responded to the religious and ritualistic contexts at the time it was given, affirmed that the Torah is eternal and will remain immutable even in messianic times. He even included this concept as one of his articles of faith, as if it were a universally accepted principle. ${ }^{31}$ However, throughout rabbinic literature, from the time of the sages until the modern period, there is another, more dynamic approach that addresses changes to the commandments in the time of the Messiah. In the words of Rabbi Yoseph: "This refers to commandments that will be annulled at the end of days." 32

This view is expressed in several midrashim. For example, in a discussion of the consumption of Leviathan and Behemoth at the end of days, it is written that God will kill them rather than ritually slaughtering them. Regarding the halakhic difficulty in this statement, Rabbi Avin bar Kahana commented: "God says: 'The Torah comes from me; innovations in the Torah also come from me." 33 A similar discussion takes place concerning forbidden foods and the laws of family purity: “'God releases the imprisoned'-What does this mean? 
There are those who say that every animal that is considered impure in this world, God will make pure in the time of the Messiah. ... What does 'release the imprisoned' mean? There is no greater prisoner (asur) than the menstruant woman, because when a woman sees blood she is forbidden (asura) to her husband, and in the time of the Messiah he will release (permit) her."34

This position was taken by commentators and thinkers throughout the generations. According to Rabbi Zaddok ha-Kohen, Korah's demand for equality among all the People of Israel was not a specious argument, but rather an idea before its time. His idea that "all the community are holy, all of them" (Num. 16:3) contains truth, but its implementation must be put off until the Messianic Era. ${ }^{35}$ From this it may be concluded that the biblical hierarchy distinguishing between Kohen, Levi, and Israel is temporary.

The same is true regarding the sacrifices in the Third Temple. Many believe that it will be built and function according to the format of the Second Temple, while others disagree. Rabbi Chaim Hirschensohn believed that no sacrifices will be offered in the Third Temple. ${ }^{36}$ Rav Kook maintained that at the beginning of the era of the Third Temple animal sacrifices will be offered, as stipulated in the Torah, but at a later stage in the distant future the moral state of the world would improve and the nature of animals would change until, as a result, animal sacrifices would stop. ${ }^{37}$ Rabbi Joseph Messas argued that sacrifices will be offered at the dedication of the Third Temple (as described in the book of Ezekiel) and afterwards abolished. ${ }^{38}$ Rabbi Messas also believed that in the Third Temple the menorah (candelabra) will run on electricity, not olive oil as in the Tabernacle and the first two Temples. ${ }^{39}$ From the above discussion it may be concluded that the Torah is the correct path to take in this world, but, as the world changes, a change will also take place in the Torah.

According to Rav Kook, the authority to change the halakhah in light of a change in morality rests with the supreme beit din in messianic times:

If a question arises concerning a law in the Torah, because, according to ethical values it would seem that it should be understood differently, if the supreme beit din decides that this law was only written in accordance with conditions that no longer exist, a source for this can certainly be found in the Torah. Concurrence between the authority of the beit din and the interpretation of the Torah are not a random coincidence. These are all words of wisdom emanating from the light of Torah and the truth of the Oral Law. We are obligated to obey the judge that will be officiating at that time. This is not a question of "development" or abbreviation. ${ }^{40}$ 
It appears that the divine origin of the Torah does not negate the fact that it was given at a specific time. The belief in the divine origin of the Torah implies the recognition that its principles are eternal, materializing in changing contexts. One who wishes to heed the central message in the laws concerning slaves - not to buy slaves, and even to fight for the abolition of slavery. One who pays close attention to the commandment regarding the beautiful captive will work to abolish sex trafficking and to promote sexual sublimation.

\section{Anachronism}

The phenomenon of anachronism, the existence of terms and verses that appear to be later in origin than the time in which the document was written, is widespread in the Bible in general and in the Torah in particular. In an interview, Rabbi Mordechai Breuer related a conversation with Rabbi Yehuda Amital about the appearance of the name "Dan" in the story of the war of the four kings in Genesis. ${ }^{41}$ ("When Abram heard that his kinsman had been taken captive, he mustered his retainers, born into his household, numbering three hundred and eighteen, and went in pursuit as far as Dan" [Gen. 14:14]). This reference to the territory of the tribe of Dan appears anachronistic because, at the time of the story, Dan had not yet been born, and, consequently, the tribe of Dan had not yet conquered territory in the north of the Land of Israel (see Judg. 18). Rabbi David Kimchi commented on this verse that the name "Dan" was either mentioned prophetically, meaning that the place was described as it would later be called, or that a different place was intended. Rabbi Breuer related that he had asked Rabbi Amital how to understand the reference to Dan, and Rabbi Amital answered him: "Was God incapable of knowing the location of the tribe of Dan even before it was established?" Rabbi Breuer recounted that this answer amazed him, revolutionized his way of thinking, and led him to develop his aspects theory. In light of the arguments presented here, I cannot accept this solution because it is completely illogical. The recipients of the Torah had to understand, in some way, what was written; it is not possible that for hundreds of years a verse in the Torah was completely unintelligible.

Rabbi Amital's answer is supported by many commentaries throughout the generations, and perhaps there are those who will see in it an indication of the uniqueness of the Torah. However, the opposite approach of searching for a logical solution that includes the human factor in the Torah 
leads to a different path, also mentioned in early and medieval rabbinic literature. The sages themselves argued about the last eight verses in the Torah:

Eight verses in the Torah were written by Joshua, as it is written: "So Moses the servant of the Lord died there" (Deut. 34:5). Now is it possible that Moses, while alive, could have written the words: "Moses died there"? Rather, up to this point Moses wrote, from this point on, Joshua wrote. This is the opinion of Rabbi Yehudah, or, according to others, of Rabbi Nehemiah. Rabbi Shimon said to him: "Can a sefer Torah be missing even one letter? And yet it is written: "Take this book of Teaching" (Deut. 31: 26). Rather, up to this point, the Holy One, blessed be He, dictated and Moses repeated and recorded, and from this point God dictated and Moses, in tears, recorded. ${ }^{42}$

This is the approach taken by Abraham Ibn Ezra who added other verses to the list of anachronisms, and alluded cryptically to the concept with the phrase "the secret of the twelve." 43 His obscure references were explained by Rabbi Joseph Bonfils, in his super-commentary Zafenat Pa'aneah, on the verse "The Canaanites were then in the land" (Gen. 12:6): "It would appear that Moses did not write this word here. Joshua or one of the other prophets wrote it ... since they were not concerned about this matter it is clear that they had the authority to add words in order to clarify, all the more so, that a prophet has the authority to add words to the prophecy of another prophet in order to explain them, especially regarding a non-legal, narrative passage. It therefore cannot be considered an interpolation."

Nachmanides also followed this approach in several places-for example, in his comment on Numbers 21:1:

Scripture continued by relating here that Israel also laid their cities waste when they came into the land of Canaan, after the death of Joshua. . . . It is with reference to this that it is stated in the book of Judges. . . . It was then that this vow [recorded here] was fulfilled but Scripture however completed the account of the matter here, just as it did in the section speaking of the descending of the manna (Exod. 16:34-35) ... [an event which occurred] after the death of Moses until "the morrow after the Passover" (Josh. 5:12). Similarly: "These are the names of the men that shall take possession of the Land for you, etc." (34:17). He should 
rather have commanded Joshua [about them] at the time of the division of the Land. ${ }^{44}$

Isaac Abravanel opposed Nachmanides' position with the argument that God has the power to dictate to Moses statements about things that will take place after his death: "Moses wrote the Torah as God commanded him, word for word. Therefore, it is not impossible that he, may he rest in peace, wrote things that would take place after his death." 45

The German Pietists also believed that the Torah contains verses added later. According to Gershon Brin, Rabbi Judah the Pious, in his commentary to Genesis 48, distinguished between three stylistic levels in the Bible. ${ }^{46}$ He identified the third level with Joshua or the men of the Great Assembly. ${ }^{47}$ Rabbi Judah the Pious also identified an interpolation from the time of the men of the Great Assembly in Deuteronomy 2:8. Israel Ta-Shma cited the from commentary of Rabbi Solomon bar Samuel Ha-Zarfati, a student of Rabbi Samuel the Pious, and his son Rabbi Judah the Pious that the name "Azazel" (Lev. 16:8) is Aramaic - a language later than the time of Moses: "Moses did not write this verse, rather someone else wrote it. Do not be shocked by my statement that someone else wrote it, because there are other such verses; that is, there are many verses not written by Moses." 48 The search for logical interpretation led commentators to add verses to this list and delete others. Sometimes there is a debate regarding a verse that some view as anachronistic, while others resolve its difficulty in another way. ${ }^{49}$ Anachronism also occurs in the Prophets and Writings, and there as well commentators have used a variety of approaches. ${ }^{50}$

\section{Approaches to Contradictions in Torah Law}

The following discussion touches on a very raw nerve. Biblical criticism claims that the Torah is compiled from several sources or traditions that were incorporated in the Torah that we have today. ${ }^{51}$ The fact that there are many contradictions, repetitions, stylistic differences, and various versions of the name of God within the Torah has led scholars to argue that the Torah is not harmonic or integrated. In addition, they argue that there is occasional unevenness in the text that can be resolved by skipping over or omitting verses to reveal an original harmonic text. Critical scholarship claims that the Bible underwent editing processes including interpolation, omission, and even adaptation of the verses.

Rabbi Mordechai Breuer was sui generis in that he accepted the arguments of critical scholarship and "translated" them into Jewish terminology. According 
to his approach, there are contradictions in the Bible, but they express the word of God in the most effective way possible. According to Breuer, God gave a Torah with internal contradictions because only by means of such tension it is possible to convey the divine truth in its entirety. The repetitions, contradictions, and changes in style are essential elements of the text. Nonetheless, he rejected the underlying assumptions of scholars who do not accept the concept of revelation and "believe" that the Torah is a human creation; he considered this belief a false axiom and an unproven opinion with no advantage over belief in the divine origin of the Torah. Acceptance of the contradictions from a position of belief in God's revelation to His people on Sinai led Rabbi Breuer to explain them as differing aspects-in other words, different points of view on the same story or law.

This is not the appropriate forum to discuss the aspects theory in all its details, but I will comment on its theological underpinnings. The difficulty here lies with pointing out God's ability to speak in a contradictory manner, while ignoring the human recipient who receives such a Torah. Is it reasonable to suggest that the recipient of the Torah, in the course of reading a legal passage, is aware that in another passage there is a contradictory position that complements it?

This point is especially valid regarding the instances in which one aspect of a law was revealed at Sinai and another forty years later on the plains of Moab. Sometimes Breuer's exegetical model is too sophisticated, and the Torah seems to be a convoluted riddle. Is the aspects theory viable? The answer is affirmative if the focus is on God's infinitude; however, the theory is not compatible with the approach that focuses on the People of Israel who received the Torah. God is able to make two contradictory statements simultaneously, but man is not capable of grasping both messages at the same time. The midrash says that shamor ("observe," Deut. 5:12) and zakhor )"remember," Ex. 20:8) were said in a single utterance, but Abraham Ibn Ezra, one of the greatest of the peshat exegetes, rejected the idea: "Even if we say that the speech of God is different from human speech, how did the People of Israel understand God's utterance? Because if a person were to hear shamor and zakhor at the same time, he would understand neither. ${ }^{52} \mathrm{Ibn}$ Ezra therefore preferred to resolve the contradiction by arguing that, in Deuteronomy, Moses changed the language of the Ten Commandments yet retained the essence of the words, because observing and remembering have the same meaning.

In light of this argument, I will present a simpler model that takes into consideration the human beings receiving the divine laws. According to this 
model, Torah legislation underwent changes: the original law was replaced by a new one according to changing realities, the need of the hour, and the ethical and spiritual level of the world at that time. ${ }^{53}$ This model can be seen explicitly in the law of basar ta'avah (meat of lust). Initially, God commanded that all meat must be slaughtered on the altar (Lev. 17). During the preparations before entering the Land of Israel and the transition to a centralized ritual, this early law was annulled, and meat was allowed to be slaughtered for consumption alone (Deut. 12:15).

This model is also clearly seen in the story of the daughters of Zelophehad. Initially only sons were to inherit from their fathers. However, the daughters of Zelophehad, who died without sons, appealed to Moses, and God decreed a change in the law: if there are no sons, the daughters will inherit from their father (Num. 27). In response, the elders of the tribe of Manasseh, who feared that the daughters of Zelophehad would marry members of other tribes and their inheritance would be lost to the tribe, appealed to Moses. God responded by making the new law conditional upon the daughters' marriage to members of their own tribe (Num. 36).

This dynamic process, presented explicitly in the Torah, is the key to understanding the entire biblical legal system. Although this model is mentioned overtly by the sages only in reference to specific commandments (the transition in methods of slaughtering, daughters' inheritance, the consumption of meat for pleasure, and the centralization of ritual) it is latent in other sources.

According to this model, the Torah's eternity lies in the ethical messages embedded in every law, and the higher purpose revealed in the changes to laws. For example, my teacher Rabbi Avia Hacohen argues that in the law of the Hebrew maidservant, as it appears in Exodus 21:7-11, the Torah permits concubinage while protecting the rights of the maidservant, and thereby establishes an ethical basis for behavior towards her. ${ }^{54}$ However, in Deuteronomy 15:12-18 the Torah forbids concubinage and permits only short-term slavery in order to prevent involuntary sexual relations. The eternal message is embedded also in the relationship between the passages. The Torah aims to increasingly better the condition of the vulnerable maidservant, and this inspired the sages to continue the trend by mandating that the master marry the maidservant when she reaches maturity. As part of this trend, they even substituted the payment given to the father in exchange for his daughter with a ketubah (marriage contract) given to the woman herself.

From the point of view of the recipient of the Torah, this solution is more logical than others. The Torah's recipients were expected to keep a new 
commandment. In every generation, the recipients of the Torah kept the Written Law that lay in front of them and was adapted to them. Whenever a new law was given, they would commit themselves to obeying it, and were not expected to perceive within it a new perspective that complements another point of view.

It must be admitted that this solution, too, is not without its difficulties. It does not explain the interweaving of verses, as in the story of the Flood. Furthermore, in order for a change in the law to be understood fully, its causes must be clarified. From a theological perspective, the question of the dating of the Torah's composition remains and must be clarified. It must be admitted that it will be difficult to explain why there were numerous changes in such a short timespan of forty years. Nonetheless, the strength of the exegetical model lies in its simplicity and its ability to provide logical interpretation based on an awareness of both sides of the prophetic nature of the Torah: God the giver and man the recipient.

This model is similar to the position of biblical scholarship in breaking the text into separate passages and then ascribing them to different times and places. It is however, the polar opposite of the secular perspective usually associated with this approach. In contrast to secular, academic exegesis from which God is absent, this model affirms revelation and the belief in a God who speaks to his people through the Torah.

\section{Endnotes}

I would like to thank Dr. Yoshi Fargeon for his helpful comments and criticisms. Special thanks to my student Aviad Avron for his great efforts in editing this article.

1. Rimon Kasher, "Ha-Nissim ba-Mikra: Yiḥudam ha-Fenomenologi, Ma’amadam ha-Te’ori, u-Mashma'utam ha-Teologit" [Miracles in the Bible: their phenomenological uniqueness, narrative status, and theological meaning], Beit ha-Mikra 31a (1986): 50.

2. While in the framework of this article, I will distinguish between divine speech and human comprehension, I am aware of the existence of more complex models of the process of revelation. See Tamar Ross, Expanding the Palace of Torah: Orthodoxy and Feminism (Hanover, NH: Brandeis University Press), 201.

3. Pesikta de-Rav Kahana, ed. Bernard Mandelboim (New York: Jewish Theological Seminary of America, 1962), 222 (piska 24, behodesh ha-shlishi).

4. Babylonian Talmud, tractate Kiddushin $17 \mathrm{~b}$.

5. Pesikta Zutarta (Lekah Tov), Ex. 24:17, s.v. u-mareh kavod.

6. On the need to express deep philosophical ideas by means of metaphor in the Torah and Prophets, see the introduction to the first part of The Guide of the Perplexed (pages 8-14 in the Pines translation). Maimonides likened the relationship between ideas and their manner of expression to "golden apples in silver showpieces" (Prov. 25:11). On the limitations of human intelligence and the Torah's use of human language, see The Guide of the Perplexed 
1:33. The relationship between the manner of divine speech and the human ability to comprehend it was discussed by Rav Kook in several places. For example, Eder ha-Yakar (Jerusalem: Mosad Harav Kook, 1967), 42; Iggrot Ha-Ra'aya (Jerusalem: Mosad Harav Kook, 1985), 102-103 (1:90, sec. 2 and 6).

7. This passage was discovered by Moshe Sokolow in a manuscript and cited by Elazar Touitou in Ha-Pashtut ha-Mithadshim be-Kol Yom [Peshat interpretations emerging daily] (Ramat Gan: Bar Ilan University, 2003), 75. In Mikra'ot Gedolot ha-Keter this passage is included at the end of Samuel ben Meir's commentary to Deuteronomy. Samuel ben Meir used similar language in his introduction to the Torah portion Mishpatim: "I will interpret the laws and the statutes according to social mores."

8. For an extensive discussion on this subject see Uriel Simon, "Mashma'uta ha-Datit shel ha-Pashtut ha-Mithadshim" [The religious meaning of the renewing peshat exegesis], in Ha-Mikra ve-Anachnu [The Bible and us], ed. Uriel Simon )Ramat Gan: Devir, 1988), 133-152.

9. Babylonian Talmud, tractate Shabbat 63a.

10. Pesikta de-Rav Kahana (Mandelboim), 355 (piska 24, Shuva). The parallel version in the Jerusalem Talmud, tractate Makot 2:6 is incomplete, as noted by Mandelboim in his edition of the Peskita de-Rav Kahana (355): "The parallel passage in the Jerusalem Talmud contains lacunae. However, the passage appears in sources from the Geniza and medieval literature. See Maimonides, Hilkhot ha-Yerushalmi le-Rambam [The laws of the Palestinian Talmud], ed. Saul Lieberman (New York: Jewish Theological Seminary of America, 1947), 67n7."

11. The distinction between God and his Torah appears in another midrash: "The Lord replied: 'Because they forsook the Teaching I had set before them' (Jer. 9:12). Rabbi Hiyya bar Ba said: 'They deserted Me' (Jer. 16:11) - I will overlook this for perchance they kept My Torah, because if they forsook Me and kept my Torah, the leaven [i.e., the enzyme or catalyst] within it would bring them back to me." (Jerusalem Talmud, tractate Hagigah, 1:7). The midrash raises a possible scenario in which the Jewish people are alienated from God, but at the same time connected to the Torah.

12. This is not the appropriate forum in which to discuss the midrash's approach to repentance. I will confine myself to one aspect of the issue. The answers given by Wisdom and Prophecy, and even the Torah, are correct but incomplete, because they are part of the system of law and order that are also the will of God. However, God's answer teaches us that repentance has the power to override the legal system, and allow the return of the repentant sinner.

13. Rabbi Dov Baer ben Avraham of Mezeritch, Magid Devarav le-Ya'akov, 297 (piska 191).

14. Ross, Expanding the Palace of Torah, 201-202. See also Yosef Chaim, Od Yosef Chai (Jerusalem: Hırev, 1950), 237, Emor, s.v. ve-lakahat.

15. Ross does not make room for peshat interpretation. See below, note 53.

16. Babylonian Talmud, tractate Megillah 13a.

17. On the phenomenon of ritual marriages, that is, a ritual performance of a sexual act to celebrate the marriage of gods, see the collected volume: M. Nissinen and U. Risto, eds., Sacred Marriages: The Divine-Human Sexual Metaphor from Sumer to Early Christianity (Winona Lake, IN: Eisenbrauns, 2008).

18. Babylonian Talmud, tractate Sanhedrin 4b.

19. Rashi on Exod. 13:16.

20. See Menahem Zevi Kaddari, Milon ha-Ivrit ha-Mikra'it [A dictionary of biblical Hebrew] (Ramat Gan: Bar Ilan University, 2006), 377, s.v. totafot.

21. Rashi on Gen. 4:1. 
22. A chiastic structure (in which words or sentences are arranged transversely) is also found in Near Eastern literature. On this subject in general see John W. Welch, ed., Chiasmus in Antiquity (Hildesheim: Gerstenberg, 1981).

23. A typological (formulaic) number is a number with a special meaning that expresses a particular idea when it appears in writing. This is an accepted literary device in poetry and prose. According to Samuel ben Meir and Abraham Ibn Ezra (as opposed to Rashi), God also expresses himself with typological numbers. See their commentaries on Lev. 26:18.

24. Pesikta Zutarta (Lekah Tov), Ex. 24:17, s.v. u-mareh kavod. This statement is also true regarding prophecy. Understanding the diversions of rivers in the Messianic Era described in Isa. 11:15 requires a familiarity with the rivers' original courses. In the modern world, in which we can travel by air it is hard to accept that the future redemption will involve changes to water transport. In a previous article, I argued that the diversion of seas and rivers is an act of divine revelation, and, in this sense, the prophecy is eternal. See Chezi Cohen, "Kriyat Yam Suf ve-Htashivuta ha-Teologit” [The Parting of the Red Sea and its theological significance], Ma'agalim 1 (1998): 23-31.

25. See, e.g., Shemuel Efraim Levinstam, "Sha'ul," in Entzeklopedia Mikrait [Encyclopaedia biblica] Jerusalem: Mosad Bialik, 1988), 7:456-457.

26. Uriel Simon, "Parashat Bereshit: Parashat ha-Bria be-Heibet Sifruti" [Parashat Bereshit: The story of creation from a literary perspective], Likrat Shabbat (2006): 11-22.

27. Babylonian Talmud, tractate Kiddushin 21b-22a.

28. The Guide of the Perplexed, 3:32.

29. Chaim Noy, Hukkim min ha-Mizrah ha-Kadum Arukhim be-makbil le-Hukkim min haTorah [Laws from the ancient Near East concurrent to the laws of the Torah] (Kiryat Tivon: Hayyim Noi, 1989), 23-24.

30. For a detailed study, see Haim Zeev Hirschberg, "Ge'ulat Dam," in Enzeklopedia Mikrait 2:392-394.

31. Maimonides affirmed this idea in his introduction to perek Helek, the ninth principle: "The Ninth Fundamental Principle is the authenticity of the Torah, i.e., that this Torah was precisely transcribed from God and no one else. To the Torah, Oral and Written, nothing must be added nor anything taken from it, as it is said, 'You must neither add nor detract' (Deut. 13:1)." Maimonides, A Maimonides Reader, ed. Isadore Twersky (New York: Behrman House, 1972), 421.

32. Babylonian Talmud, tractate Niddah $61 \mathrm{~b}$.

33. Va-yikra Rabbah, Shemini, 13:3. For a survey of the midrashim, see http://www.aharit.com/ A-12html.

34. Midrash Shoher Tov, Psalms, piska 146, 4.

35. See Avia Hacohen, "Parashat Korah: Al Sovlanut be-De'ot ve-Shivyon" [The story of Korah: On intellectual tolerance and equality], Mishlav 15) 1990): 57-71.

36. Rabbi Chaim Hirschensohn, Malki ba-Kodesh (St. Louis, MO: Moniester, 1919), 1:8-9. On the argument between Rav Kook and Rabbi Hirschensohn, see Eyal Ben-Eliyahu, "LeHakim Binyan Hadash': Ha-Rav Kook, ha-Rav Hirschensohn ve-Herzl al Binyan ha-Mikdash veHidush ha-Korbanot" [To build a new building: Rav Kook, Rabbi Hirschensohn, and Herzl on the rebuilding of the Temple and the renewal of sacrifices], Katedra 128 (2008): 101-112.

37. Rav Abraham Isaac ha-Kohen Kook, Hazon ha-Tzimhịonut ve-ha-Shalom [The vision of vegetarianism and peace], ed. David Cohen )Jerusalem: Netzer David Ariel, 1983); Siddur Olat Ra'aya (Jerusalem: Mosad Harav Kook, 1985), 292. 
38. Rabbi Joseph Messas, Otzar Ha-Miktavim (Husiatyn: Kolak, 1905), 2:1305, also published in Masoret be-Aidan Moderni: Hakhamim Sefaradim be-Dorot ha-Aharonim [Jewish heritage in modern times], ed. Rabbi Itshak Shouraqui (Tel Aviv: Miskal, 2009), 230.

39. Rabbi Joseph Messas, Ner Mitzva (Jerusalem: Makhon Bnei Yisakhar, 1999), 15, also published in Masoret be-Aidan Moderni, 229.

40. Iggerot Ha-Ra'aya, 1:90

41. Rabbi Mordechai Breuer, Shitat ha-Behinot shel ha-Rav Mordekhai Breuer [The aspects theory of Rabbi Mordechai Breuer], ed. Yosef Ofer (Alon Shvut: Tvunot, 2005), 341.

42. Babylonian Talmud, tractate Bava Batra 15a.

43. A complete list can be found in Uriel Simon, "Shenayim Ohazim be-'Sod ha-Sheim-asar' shel Rav Avraham ibn Ezra" [Two who fight over the "secret of the twelve" of Rabbi Abraham Ibn Ezra], Megadim 51 (2010): 77-85.

44. Nachmanides, Commentary on the Torah, trans. and ed. Charles B. Chavel (New York: Shilo, 1975), 230-231.

45. Abravanel, ed. Yehuda Shaviv (Jerusalem: Horev, 2007), commentary to Num. 21.

46. Gershon Brin, "Kavim le-Perush ha-Torah shel Rabbi Yehuda he-Hasid" [An introduction to the commentary of Rabbi Judah the Pious], Teudah 3 (1983): 215-226.

47. See Baruch J. Schwartz, "Perush Rabbi Yehudah He-Hasid le-Bereshit 48:20-22" [The commentary of Rabbi Judah the Pious to Genesis 48:20-22], Tarbiz 80 (2012): 29-39.

48. Israel Ta-Shama, "Mashahu al Bikoret ha-Mikra be-Ashkenaz be-Yimmei ha-Benayim" [Notes on biblical criticism in Germany in the Middle Ages], in Ha-Mikra be-Re'i Mefarshav [The Bible as seen by its commentators], ed. Sara Japhet (Jerusalem: Magnes, 1994), 453-459.

49. For example, in his comment on Gen. 36:31, Abraham Ibn Ezra forcefully rejected the opinion of the "Yitzhaki" that the list of the kings of Edom was from the days of Jehoshaphat.

50. For example, biblical scholarship has revealed differences in both language and content between the first part of the book of Isaiah (1-39) and the second part (40-66). In addition, the second part refers to the Babylonian exile and the return to Zion following the declaration of Cyrus (44-45), and a call to return from captivity in Babylon and rebuild the Temple (48:20). As a result, biblical scholars argued that the second part of the book was written by another prophet in the time of the return to Zion. In keeping with the thesis outlined here, I cannot accept the position that the second part of the book is the prophecy of Isaiah merely on the basis of the argument that a prophet can speak of events that took place 150 years after his time. In fact, a prophet can describe distant events, but is it logical that he would make prophesies that his audience would be unable to understand? It seems to me that the answer to this question is negative, and that we must therefore seek other answers to the question of discrepancies between the two parts of the book. See the discussion of Amos Hakham, Da'at Mikra, Yishayahu (Jerusalem: Mosad ha-Rav Kook, 1984), 14-17; Avia Hacohen, "Ha-Omnam Ehad Haya Yishayahu?" [Was there only one Isaiah?], Derekh Efrata 9-10 (2001): 79-88.

Another example is the reference to Josiah by name in the prophecy of the "man of God" (1 Kings 13:2) about three hundred years before the king's birth. See Yehuda Elitzur, "Eumna u-Mada be-Parshanut ha-Mikra: Ekronot, Tehumin u-Kavanot" [Faith and science in biblical exegesis: Principles, areas, and intentions], in Emuna, Dat u-Mada [Faith, religion, and science] (Jerusalem: Ministry of Education, 1966), 19.

51. For a summary of biblical criticism see (among other sources) Yair Hoffman, Sugiot be-Bikoret ha-Mikra [Essays on biblical criticism] (Tel Aviv: Ha'universita Hameshuderet, 1997).

52. Ibn Ezra on Exod. 20:1. 
53 On this type of exegesis, see Avia Hacohen, "Be-Ikvei Beur ha-Gra le-Parasht Ama Ivria" [In the footsteps of the commentary of the Vilna Gaon to the commandment of the Hebrew maidservant], in Sefer ha-Yovel le-Rav Mordechai Breuer [Mordechai Breuer Jubilee Volume], ed. Moshe Bar-Asher (Jerusalem: Akademon, 1992), 1:77-87; David Bigman and Avia Hacohen, "Parashat Sotah," Mishlav 29 (1996): 11-21; Chezi Cohen, "Mah Bein Pesach be-Shemmot le-Pesach be-Devarim?" [What is the difference between Passover in Exodus and Passover in Deuteronomy?], Akdamut 26 (2011): 41-56. A collection of articles on the developmental approach is soon to be published by Yeshivat Ma'aleh Gilboa.

On this basis, it is possible to speak of the idea of the cumulative revelation discussed by Shalom Rosenberg's "Ha-Hitgalut ha-Matmedet: Shlosha Kivunim" [The continual revelation: three directions], in Hitgalut, Emuna, Tevuna [Revelation, faith, understanding], ed. Moshe Hallamish and Moshe Schwarcz (Ramat Gan: Bar Ilan University, 1976), 131-143; and Tamar Ross's Expanding the Palace of Torah, 197 and following. Nonetheless, it is important to make three distinctions between the model proposed by these two scholars of Jewish thought and the ideas presented here: First, both of these scholars relate to the Written Torah as one unit, and discuss a series of "hearings" of what was said at Sinai reverberating throughout Jewish history; the reference is to commentaries and halakhic rulings (Ross, 197-200). I, on the other hand, am referring to a continuum of revelations over many years from which the Written Torah itself was compiled. Second, Ross warmly embraces the rabbinic tradition that the meaning of the Torah is "looser and richer than a strictly literal historical understanding" (199). I argue that the Torah has a logical interpretation, which is the peshat that commentators have disputed, as distinct from the midrash, the remez, and the sod. Third, Ross, in her comments about the term "revelation," rejects an absolute distinction between the divine and the human (200-201). Although I agree with her on the third point, I did not deem it appropriate to discuss the idea in this article.

54. Avia Hacohen, "Be-Ikvei Beur ha-Gra le-Parashat Ama Ivria." 